\title{
Effect of hepatitis $C$ virus on the central nervous system of HIV-infected individuals
}

\author{
This article was published in the following Dove Press journal: \\ Virus Adaptation and Treatment \\ 15 November 2012 \\ Number of times this article has been viewed
}

\section{Markus Gess \\ Daniel Forton \\ Department of Gastroenterology and Hepatology, St George's \\ University of London, London, UK}

Correspondence: Daniel Forton

Department of Gastroenterology and Hepatology, St George's University of London, Blackshaw Road, London SWI7 0QT, United Kingdom

Tel +442087253520

Fax +44 2087253032

Email dforton@sgul.ac.uk
Abstract: Infection with the human immunodeficiency virus (HIV) is associated with a spectrum of neuropsychiatric manifestations ranging from asymptomatic cognitive impairment, detectable only by sensitive neurocognitive tests, to overt HIV-associated dementia. Highly active antiretroviral therapy has led to significant reductions in the incidence of severe HIVassociated dementia. However, the overall prevalence of milder HIV-associated cognitive disorders appears to be increasing as HIV-infected subjects live longer in the era of combined antiretroviral treatments. Chronic hepatitis $\mathrm{C}$ virus (HCV) infection is also associated with neuropsychological symptoms and impaired cognitive performance in some patients, and recent evidence suggests that these central nervous system (CNS) symptoms may be caused by HCV entry into the brain via endothelial infection. Similarly to the neuropathological processes in HIV infection, microglial activation in HCV infected subjects may underlie the CNS metabolic abnormalities and impaired cognitive performance that have been described in studies of HCVinfected cohorts. A significant proportion of HIV-infected subjects are coinfected with HCV, but the impact and clinical importance of coinfection on cognitive function has only been addressed in a small number of research studies. There is some evidence that coinfection may adversely affect neurocognitive function; however, studies published thus far are limited by a number of confounding factors and small sample sizes. This article aims to review the current evidence examining neurocognitive function in HIV- and HCV-monoinfection and further critically discusses previous studies that have explored the impact of coinfection with HCV on CNS function of HIV-infected cohorts. It is clear that, as the population of HIV-infected individuals ages and neurocognitive disorders persist in the post-combination antiretroviral treatment era, a better understanding of the neuropathological processes and improved characterization of deficits is required to allow development of better treatments. At the advent of interferon-free, directly acting antiviral therapies against HCV, this is increasingly important. The impact of CNS infection by these viruses remains poorly understood, both in terms of neurocognitive symptoms and as a potential mechanism for HCV virological relapse after treatment.

Keywords: neurocognitive function, HIV/HCV coinfection, neuroinflammation, microglia

\section{Introduction}

An estimated 33.2 million people worldwide are infected with $\mathrm{HIV},{ }^{1}$ and an estimated 170 million with the hepatitis $\mathrm{C}$ virus $(\mathrm{HCV}) .^{2}$ Both viruses share routes of transmission and risk factors. Coinfection with HCV is commonly observed in persons with HIV infection. Evidence from large-scale studies suggests that approximately one-third of HIV-infected individuals are coinfected with HCV, with significantly higher coinfection rates in cohorts of injection drug users. ${ }^{3}$ Since HIV was first identified as 
the cause of AIDS in the early 1980s, it has been clinically apparent that HIV infection can produce neuropsychiatric disorders, ranging from asymptomatic cognitive impairment to dementia. The patterns of neurocognitive deficits observed in HIV-1 monoinfection are thought to be consistent with disrupted circuitry between the prefrontal cortex and subcortical structures and are consistent with data from autopsy series and neuroimaging studies, which have shown predominant subcortical involvement. ${ }^{4-7}$

A potential effect of $\mathrm{HCV}$ infection on the central nervous system (CNS) has been examined by a number of groups, following the discovery, using proton magnetic resonance spectroscopy (MRS), that HCV-infected patients without significant liver disease demonstrated cognitive impairment and altered cerebral metabolism. ${ }^{8-10}$ Approximately one-third of patients with chronic $\mathrm{HCV}$ infection have mild cognitive impairment, with deficits similar to those described in HIV monoinfection. ${ }^{11}$ These deficits have been reported in a number of different cohorts and appear to occur in the absence of significant liver disease and are independent of confounding factors such as a history of drug use..$^{8-21}$

Significantly less is known regarding the impact of $\mathrm{HCV}$ coinfection on neurocognitive function in HIV-infected individuals. Fewer studies have been published on this subject, most of which have reported a detrimental effect of coinfection with $\mathrm{HCV}$ on neurocognitive processes when compared to HIV alone; ${ }^{22-29}$ some studies, however, failed to demonstrate a significant impact of coinfection over HIV monoinfection. ${ }^{30-33}$

In this review we have summarized what is currently known about the individual effects of HIV and HCV infection on neurocognition and the impact of coinfection.

\section{HIV infection and the brain}

HIV infection of the CNS may result in a number of distinct syndromes unrelated to the effect of opportunistic infections, which occur as a consequence of immunodeficiency. Before the advent of highly active antiretroviral treatment (HAART), many HIV-infected patients developed severe progressive cognitive and motor impairment in the final stages of their disease. This clinical syndrome was characterized by mental slowing, attention and memory deficits, slowing of motor function with balance problems, apathy, social withdrawal, and mood disturbances and was termed AIDS dementia complex (ADC) by Navia et al in the 1980 s. $^{6,34}$ These complications were found to be associated with neuropathological changes within basal ganglia and white matter. ${ }^{35,36}$
Clinically overt cognitive deficits are not characteristic of the early stages of HIV infection, with worsening impairments evident through disease progression. The wide range of neurocognitive abnormalities associated with HIV infection have recently been summarized under the acronym HIVassociated neurocognitive disorders (HANDs). ${ }^{37}$ Three stages of neurocognitive impairment are defined: asymptomatic neurocognitive impairment (ANI), HIV-associated mild neurocognitive disorder (MND), and HIV-associated dementia (HIV-D). These replace the previous definitions of ADC/HIV-associated dementia (HAD) and minor cognitive motor disorder (MCMD). ANI is characterized by impaired performance on neurocognitive testing, at least 1 standard deviation (SD) below normative scores, in at least 2 of 5 cognitive areas tested that cannot be explained by any other comorbidity. A diagnosis of MND requires impaired everyday functioning, while HIV-D is characterized by neurocognitive impairment at least $2 \mathrm{SD}$ below the normative mean in at least two cognitive domains with marked difficulties in activities of daily living.

Before antiretroviral therapy, over $15 \%$ of late-stage HIV-infected individuals developed HIV-associated dementia and $50 \%$ of infected individuals developed some form of HAND. ${ }^{38,39}$ In recent years, the prevalence of HIV-associated dementia has decreased to less than $5 \%$, but the proportion of individuals with mild neurocognitive disorder has remained at around $20 \%$. The prevalence of asymptomatic neurocognitive impairment has increased to $25 \%$. Thus, $50 \%$ of HIVinfected individuals still develop HAND. Asymptomatic HIV-infected individuals have been shown to display deficits in attention/processing speeds and working memory on formal neurocognitive testing, ${ }^{40,41}$ while HIV patients with MCMD demonstrated slowed processing speeds, impaired sustained and divided attention, and impaired learning ability. ${ }^{42,43}$

\section{Neuroimaging}

Magnetic resonance imaging (MRI) shows normal brain appearances or only nonspecific changes in $\mathrm{MCMD}^{44}$ while patients with HIV-D display atrophic changes and deep white matter lesions. ${ }^{45}$ Brain atrophy was thought to be progressive before HAART became available ${ }^{46}$ but appears to be nonprogressive in the combination antiretroviral therapy (cART) era. ${ }^{47}$

MRS enables measurement of metabolite concentrations in different brain regions and has been used to identify cerebral abnormalities at earlier stages in both cognitively impaired $^{48}$ and asymptomatic HIV patients. ${ }^{49}$ Chang et al 
demonstrated elevated frontal white matter concentrations of myoinositol (mI) and choline (Cho) with increasing levels of cognitive impairment, ${ }^{50}$ findings consistent with CNS glial cell proliferation and cell membrane injury, respectively. MRS studies prior to antiviral treatment in patients with cognitive impairment have revealed reduced levels of frontal white matter and basal ganglia $\mathrm{N}$-acetylaspartate (NAA), a marker of neuronal integrity, and increased levels of $\mathrm{mI}$, which reverse with cART. ${ }^{51}$

\section{Neuropathology}

The pathology of the HIV-infected brain is characterized by enhanced leukocyte infiltration, microglial activation and nodule formation, aberrant expression of inflammatory factors, neuronal dysregulation and loss, and blood-brain barrier disruption. Neuropathological descriptions of postmortem brains in the pre-HAART era frequently featured atrophy in individuals with HIV encephalopathy. Basal ganglia and central white matter multinucleated giant cells were characteristic and were accompanied by a variable degree of white matter pathology. ${ }^{52}$ Microglial activation and reactive astrocytosis, accompanied by significant neuronal loss, was described as a prominent feature, sometimes with focal microglial nodules in gray and white matter. ${ }^{53}$

Only a few neuropathological studies of asymptomatic HIV-infected individuals in the early stages of infection exist. These studies have mainly been limited to individuals who died accidentally or drug users who died of drugrelated complications. Findings in such cohorts have shown low-grade lymphocytic infiltration in the leptomeninges and perivascular spaces of the central white matter and also describe microgliosis and astrocytosis. ${ }^{54,55}$ More recently, concerted efforts have been made to understand the spectrum of HIV-related brain pathology in the HAART era. The National NeuroAIDS Tissue Consortium (NNTC) in the United States has made it possible to study brain samples from larger cohorts with advanced HIV disease, ${ }^{56}$ which has shown that HIV-associated parenchymal brain pathology (encephalitis, leukoencephalopathy, and microglial nodular encephalitis) may occur less frequently than stated in previous pre-antiretroviral reports. In these highly selected cohorts of patients with advanced HIV disease, brain pathology appears to relate to lower nadir CD4 counts and higher plasma viral loads.

HIV has been shown to infect microglia, astrocytes, oligodendrocytes, and neurons. ${ }^{57-59}$ Microglial cells and macrophages are thought to be the only CNS-resident cells capable of supporting productive infection in vivo ${ }^{60}$ and represent the main CNS target of HIV infection. Damage to oligodendroglia and neurons constitutes a major component of the pathological picture and likely forms the basis of CNS symptoms in AIDS. ${ }^{52}$ There is, however, little evidence that HIV infects neurons in vivo and it is thought that other HIVinfected cells within the CNS release factors, including viral proteins, that are toxic to neurons. ${ }^{38}$

Despite effective cART, HIV persists in a number of cellular reservoirs (including monocytes, microglia, and astrocytes) and sanctuary sites such as the brain. ${ }^{61}$ Some neuropathologic studies since the introduction of HAART have indicated that antiviral treatment may not reduce neuroinflammation, and microglial activation in particular, as might have been expected, but the predominant sites of neuroinflammation appear to have changed. Post-HAART specimens have shown pronounced neuroinflammation in the hippocampus and adjacent parts of entorhinal and temporal cortex, while pre-HAART cases showed predominant involvement of basal ganglia. ${ }^{34}$

\section{Viral proteins and variants}

Microglia and brain macrophages are thought to mediate neurological disease in HIV infection by releasing neurotoxic viruses or viral proteins ${ }^{62}$ such as cleaved gp120, which has been demonstrated to damage neurons in vitro, ${ }^{63}$ and the HIV transactivator protein Tat, which may indirectly induce neuronal apoptosis ${ }^{64}$ and can be found in serum and brain tissue of individuals with HIV encephalitis. Specific mutations in the V1 and V3 gp120 loops have been identified in individuals with HIV-associated dementia, suggesting adaptation of the virus to the brain through changes in gp $120 .{ }^{65}$ Tat induces release of cytokines and chemokines from microglia, macrophages, neurons, and astrocytes in the CNS and is capable of disrupting the blood-brain barrier. ${ }^{66}$

Several other HIV proteins have been reported to have neurotoxic properties, but it is unclear if protein concentrations found to be neurotoxic in vitro are present at relevant levels in vivo. ${ }^{62} \mathrm{HIV}$-associated neurotoxic events ultimately result in neuronal apoptosis, which can be detected in the brains of individuals with HAD, particularly in brain regions with multinucleated giant cell formation.

There is evidence that the genetic heterogeneity of HIV may play a role in microglial infection. It has been shown that viruses infecting the CNS differ from HIV strains prevalent in the systemic circulation. ${ }^{67}$ The primary determinant of HIV neurotropism is macrophage tropism, which is primarily determined by variations in the viral envelope $(e n v)$ gene. ${ }^{68}$ Macrophage-tropic (M-tropic) HIV-1 isolates primarily use 
CCR5 as a co-receptor. However, it is currently unclear whether neurotropic and/or neurovirulent HIV-1 variants evolve as well as the extent of their role in the pathogenesis of HIV-related CNS dysfunction.

Dunfee et al have demonstrated that an HIV envelope (Env) glycoprotein variant in the CD4-binding site of gp120, Asn 283 (N283), is present at a high frequency in brain tissue from AIDS patients with HAD, indicating an association of an HIV variant with AIDS-related CNS complications. ${ }^{69}$ The N283 variant enhances the capacity of Envs to mediate fusion and entry when cells express low levels of CD4 and preferentially enhances viral replication in macrophages and microglia. These findings constitute an example of enhanced HIV neurotropism by lowering the threshold levels of CD4/ CCR5 required for infection.

\section{Impact of antiretroviral therapy on HIV-associated CNS dysfunction}

Severe HIV-D has become a rare phenomenon, and the incidence of severe cognitive decline has decreased significantly since the introduction of HAART. ${ }^{70,71}$ However, in recent years there appears to be a rising prevalence of minor cognitive decline, ${ }^{72,73}$ which is reported to range between $20 \%-50 \%{ }^{74-76}$ The estimated overall prevalence of HANDs in the nonviremic HIV-positive population (longstanding, undetectable HIV-1 RNA) is reported to be as high as $69 \%{ }^{36}$

However, an attenuated form of HIV-D is becoming more common as more individuals live longer with HIV/AIDS on cART. ${ }^{77,78}$ Rather than being relentlessly progressive, this milder dementia may remain static. ${ }^{79}$ Thus, cART can be considered to confer a neuroprotective effect, ${ }^{73}$ but without full protection against the development of HIV-D, possibly as a consequence of the limited CNS penetration of many antiretroviral drugs. Long-term HAART may be associated with drug-related neurotoxicity, ${ }^{80}$ even though definitive evidence for CNS toxicity related to ART has not been established..$^{81}$

A few case studies have reported neurological deterioration following initiation of cART, despite improved CD4 counts and HIV loads. These reports suggest that immune reconstitution inflammatory syndrome (IRIS) may be responsible for worsening HANDs in a small number of cases. $^{82,83}$

\section{HCV infection and the brain}

The most frequently reported symptoms in subjects with chronic $\mathrm{HCV}$ infection are related to the CNS. Many patients complain of neuropsychological symptoms such as fatigue, depression, and difficulties with concentration ("brain fog"). ${ }^{84-86}$ These extrahepatic symptoms are associated with impaired health-related quality of life (HRQL) and appear to improve with successful antiviral therapy. ${ }^{87-89}$ Cohort studies have not shown a consistent relationship between markers of liver function, HCV viral load, viral genotype, or a history of recreational drug use. ${ }^{9,87,88,90}$ However, because liver cirrhosis is a common finding in $\mathrm{HCV}$-infected groups, minimal hepatic encephalopathy (MHE) must be taken into account as an important confounder. Patient groups with liver cirrhosis of any etiology have significant impairments on neurocognitive testing batteries, in the absence of clinical signs of overt hepatic encephalopathy. ${ }^{91-93}$ Studies in cirrhotic cohorts have demonstrated impaired psychomotor speed, visual perception, and attention with preserved verbal ability, a constellation of deficits defined as MHE. ${ }^{94}$ In studies assessing neurocognitive performance in $\mathrm{HCV}$-infected subjects, it is therefore crucial to control for liver cirrhosis.

Research examining the effects of $\mathrm{HCV}$ on the CNS is far less developed than that for HIV, but there appear to be a number of neurocognitive, neurometabolic, and virological parallels between the two infections. Evidence increasingly points to a neurobiological effect of $\mathrm{HCV}$, with a number of hypothesized mechanisms that may contribute to neuroinflammation and measurable CNS metabolite abnormalities. The patterns of impaired cognitive functioning in chronic $\mathrm{HCV}$ infection have been compared to the cognitive deficits in ANI and MRS studies have demonstrated similar cerebral metabolic changes.

\section{Studies of cognitive function in chronic HCV infection}

There is increasing evidence of HCV-associated cerebral dysfunction, which can occur at an early stage of HCVinfection in the absence of advanced liver disease. ${ }^{12-15,95,96}$ Mild but significant neurocognitive impairment has been documented in a proportion of $\mathrm{HCV}$-infected patients with minimal or absent liver disease and, most commonly, deficits in attention and working memory have been described.

Since the description in 2001 of cerebral metabolic abnormalities in the frontal white matter and basal ganglia using MRS, ${ }^{8}$ a number of studies have investigated cognitive performance in $\mathrm{HCV}$-infected cohorts. These studies have often been limited by heterogeneous cohorts without adequate exclusion of potential confounding factors such as advanced liver fibrosis or cirrhosis, a history of previous intravenous drug use (IVDU), recent interferon-based 
antiviral therapy, or CNS-active medication. Furthermore, different neuropsychological tests assessing different aspects of cognitive function have been used rather than standardized batteries. These factors limit the validity of comparisons between studies. The relevant studies in this field are listed in Table 1.

One study showed that a group of viremic HCV patients with mild liver disease showed more cognitive impairment on more tasks than a matched group of subjects who had previously cleared HCV infection. ${ }^{9}$ These deficits were independent of previous drug use. The authors also found CNS metabolic abnormalities in basal ganglia and white matter on ${ }^{1} \mathrm{H}$ MRS scanning in a subgroup of the HCVpositive cohort and concluded that a biological process may underlie impaired cognitive function in HCV-patients with active viral replication. Hilsabeck et al performed two studies in this field $d^{11,12}$ and found a significant relationship between cognitive test performance and fibrosis stage on liver biopsy. However, HCV patients with minor hepatic injury also demonstrated cognitive dysfunction in the attention and concentration domains, with impairment in up to $50 \%$ of noncirrhotic HCV-infected patients. The pattern of impairment was similar to that described by Forton et $\mathrm{al}^{9}$ and was thought to be consistent with frontal-subcortical dysfunction, similar to the pattern in HIV infection. ${ }^{40}$ Weissenborn et $\mathrm{al}^{96}$ showed that HCV patients with normal liver function tests were impaired in the domains of attention and higher executive function. Patients with self-reported fatigue performed worse on the psychometric tests. Brain ${ }^{1} \mathrm{H}$ MRS showed cerebral metabolite abnormalities in the gray matter of $\mathrm{HCV}$ patients compared to controls, but no significant correlation between psychometric data and MRS cerebral metabolite data was observed.

Kramer et al ${ }^{13,16}$ measured $\mathrm{P} 300$ event-related potentials to assess neurocognitive processing in $\mathrm{HCV}$-infected patients and found significant impairments compared to matched healthy subjects, independent of the degree of liver disease, viral load, and history of IVDU. A total of $18 \%$ of the latencies were outside the age-adjusted normal range, consistent with subclinical cognitive impairment.

Conversely, evaluation of cognitive function at different stages of HCV-related liver disease by Cordoba et $\mathrm{al}^{17}$ showed significant cognitive impairment only in cirrhotic patients with a history of previous hepatic decompensation, while patient groups with mild chronic hepatitis and compensated cirrhosis were reported not to have any demonstrable cognitive impairment. This study was conducted to identify infected subjects at blood donation and may therefore have selected a cohort in good health with preserved cognitive function. ${ }^{97}$

McAndrews et $\mathrm{al}^{14}$ applied strict exclusion criteria in an attempt to minimize confounding factors and showed minimally poorer learning efficiency in a small proportion of $\mathrm{HCV}$ patients compared to controls, with only $13 \%$ considered clinically impaired. Other measures assessing attention and speed of processing were not impaired in this study. However, cerebral MRS abnormalities were reported (Table 1).

Fontana et al studied a patient cohort with advanced liver fibrosis who were enrolled in the Hepatitis C Antiviral Longterm Treatment against Cirrhosis (HALT-C) trial and found that $33 \%$ were cognitively impaired on a composite score of ten neuropsychological tests, with verbal recall and working memory being the most affected domains. ${ }^{18}$ A significant proportion (38\%) had cirrhosis, however, which constitutes a significant confounder as working memory is known to be negatively affected by advanced liver disease and hepatic encephalopathy. ${ }^{98}$

A recent Irish study of a small, homogenous cohort of iatrogenically infected women, of whom nine had spontaneously cleared $\mathrm{HCV}$, showed that polymerase chain reaction (PCR)-positive women had more impaired memory and attention compared to normal controls and the PCRnegative group. ${ }^{19}$

Huckans et $\mathrm{al}^{15}$ attempted to control for substance use disorder (SUD) and showed that $\mathrm{HCV}+/ \mathrm{SUD}-$ patients performed worse than the HCV-/SUD- control group in verbal learning and attention domains. Their results suggest that $\mathrm{HCV}$ infection is associated with cognitive impairment in the absence of a history of SUD.

Perry et $\mathrm{al}^{99}$ recently reviewed the studies in this field and concluded that the combination of evidence from neuropsychological, neurophysiologic and neuroimaging studies provided "strong support for the presence of an attentional deficit mediated by frontal subcortical circuitry in a group of patients infected with HCV."

\section{Neuroimaging}

MRS, ${ }^{8,9,14,20,96,100}$ positron emission tomography (PET), ${ }^{100,101}$ and single-photon emission computed tomography ${ }^{102}$ have been used to investigate whether altered cerebral metabolism and/or neurotransmission occur in chronic HCV infection. In a cohort of $\mathrm{HCV}$-infected patients with histologically proven mild disease, ${ }^{8,9}$ the cerebral Cho to creatine $(\mathrm{Cr})$ ratio was elevated in the basal ganglia and white matter, a finding that was not related to previous substance abuse. This abnormality 
Table I Studies of cognitive function in HCV-infected patients with mild liver disease

\begin{tabular}{|c|c|c|c|c|}
\hline Study & Sample & Measures & Findings & Limitations \\
\hline $\begin{array}{l}\text { Forton } \\
\text { et al }{ }^{8}\end{array}$ & $\begin{array}{l}30 \mathrm{HCV} \\
29 \text { controls } \\
12 \mathrm{HBV}\end{array}$ & 'H MRS & $\begin{array}{l}\text { Elevated Cho in HCV; independent } \\
\text { of IVDU }\end{array}$ & $\begin{array}{l}\text { No cognitive function } \\
\text { data }\end{array}$ \\
\hline $\begin{array}{l}\text { Forton } \\
\text { et al }{ }^{9}\end{array}$ & $\begin{array}{l}27 \text { chronic HCV } \\
16 \mathrm{HCV} \text {-cleared }\end{array}$ & $\begin{array}{l}\text { 'H MRS } \\
\text { Neuropsychological measures } \\
\text { Computerized cognitive battery }\end{array}$ & $\begin{array}{l}\text { HCV-infected more impaired on } \\
\text { concentration and working memory } \\
\text { than HCV-cleared; independent of } \\
\text { depression, fatigue }\end{array}$ & Small sample \\
\hline $\begin{array}{l}\text { Weissenborn } \\
\text { et } \mathrm{al}^{10}\end{array}$ & $\begin{array}{l}30 \mathrm{HCV} \text { ( } 15 \text { with } \\
\text { mild and } 15 \text { moderate- } \\
\text { to-severe fatigue) } \\
15 \text { controls }\end{array}$ & $\begin{array}{l}\text { a. Depression and anxiety scores } \\
\text { b. Neuropsychological tests for } \\
\text { attention, memory, learning, visual } \\
\text { perception and construction, } \\
\text { psychomotor speed } \\
\text { c. 'H MRS } \\
\text { d. EEG }\end{array}$ & $\begin{array}{l}\text { Impaired attention and higher } \\
\text { executive functions in HCV } \\
\text { compared to controls; greater } \\
\text { levels of anxiety and depression; } \\
\text { EEG slowing in } 25 \% \mathrm{HCV} \text { patients; } \\
\text { decreased NAA in HCV }\end{array}$ & Small sample \\
\hline $\begin{array}{l}\text { Hilsabeck } \\
\text { et al" }\end{array}$ & $21 \mathrm{HCV}$ & $\begin{array}{l}\text { a. Battery of neuropsychological tests } \\
\text { for attention, visuoconstructional } \\
\text { ability, learning, memory, } \\
\text { psychomotor speed } \\
\text { b. Fatigue, depression, anxiety scores, } \\
\text { cognitive complaints }\end{array}$ & $\begin{array}{l}\text { Greater impairment associated } \\
\text { with fibrosis; up to } 38 \% \text { impaired in } \\
\text { attention and psychomotor speed; } \\
\text { no relationship with depression, } \\
\text { fatigue, or cognitive complaints }\end{array}$ & Small sample \\
\hline $\begin{array}{l}\text { Hilsabeck } \\
\text { et al }{ }^{12}\end{array}$ & $\begin{array}{l}66 \mathrm{HCV} \\
14 \text { other liver disease }\end{array}$ & $\begin{array}{l}\text { Battery of neuropsychological tests for } \\
\text { attention, visuoconstructional ability, } \\
\text { learning, memory, psycho-motor speed }\end{array}$ & $\begin{array}{l}\text { Relationship between liver fibrosis } \\
\text { and cognitive impairment; cognitive } \\
\text { impairment exists in noncirrhotics }\end{array}$ & Cirrhotics not excluded \\
\hline $\begin{array}{l}\text { Kramer } \\
\text { et } \mathrm{al}^{13}\end{array}$ & $\begin{array}{l}100 \mathrm{HCV} \\
100 \text { controls }\end{array}$ & $\begin{array}{l}\text { a. P300 event-related potentials } \\
\text { b. QOL and fatigue scores }\end{array}$ & $\begin{array}{l}\text { Prolonged P300 latencies in } 17 \% \text { of } \\
\mathrm{HCV} \text { subjects; independent of } \\
\text { fibrosis, viral load, history } \\
\text { of IVDU, and fatigue }\end{array}$ & $\begin{array}{l}\text { No neuropsychological } \\
\text { testing }\end{array}$ \\
\hline $\begin{array}{l}\text { McAndrews } \\
\text { et al }{ }^{14}\end{array}$ & $\begin{array}{l}37 \mathrm{HCV} \\
42 \text { controls }\end{array}$ & $\begin{array}{l}\text { a. Neuropsychological tests for } \\
\text { learning, attention, psychomotor } \\
\text { speed, cognitive flexibility } \\
\text { b. Fatigue and depression scores } \\
\text { c. 'H MRS }\end{array}$ & $\begin{array}{l}\text { Learning deficits only in small } \\
\text { proportion of HCV patients (I3\%); } \\
\text { minor attention deficits; increased } \\
\text { Cho and decreased NAA in central } \\
\text { white matter; no association with } \\
\text { depression or fatigue }\end{array}$ & $\begin{array}{l}\text { Multiple exclusion } \\
\text { criteria limiting } \\
\text { generalizability }\end{array}$ \\
\hline $\begin{array}{l}\text { Huckans } \\
\text { et } \text { al }^{15}\end{array}$ & $\begin{array}{l}39 \mathrm{HCV}+/ \mathrm{SUD}+ \\
24 \mathrm{HCV}+/ \mathrm{SUD}- \\
56 \mathrm{HCV}-/ \mathrm{SUD}-\end{array}$ & $\begin{array}{l}\text { Battery of neuropsychological tests } \\
\text { for language, memory, attention, } \\
\text { information processing, motor speed, } \\
\text { visuomotor construction and mental } \\
\text { flexibility }\end{array}$ & $\begin{array}{l}\mathrm{HCV}+/ \mathrm{SUD} \text { patients impaired in } \\
\text { learning, attention, and reasoning } \\
\text { versus controls; } \mathrm{HCV}+/ \mathrm{SUD}+ \\
\text { impaired in information processing; } \\
\text { evidence for cognitive impairment } \\
\text { in absence of SUD }\end{array}$ & $\begin{array}{l}\text { Cirrhosis not definitively } \\
\text { excluded }\end{array}$ \\
\hline $\begin{array}{l}\text { Kramer } \\
\text { et al }{ }^{16}\end{array}$ & $\begin{array}{l}120 \mathrm{HCV} \\
100 \text { controls }\end{array}$ & $\begin{array}{l}\text { a. P300 event-related potentials } \\
\text { b. QOL and fatigue scores }\end{array}$ & $\begin{array}{l}\text { Increased fatigue in HCV; fatigue } \\
\text { and age related to QOL; I8\% of } \\
\mathrm{HCV} \text { patients delayed latencies; } \\
\text { subclinical cognitive impairment } \\
\text { not related to impaired QOL }\end{array}$ & $\begin{array}{l}\text { No neuropsychological } \\
\text { testing }\end{array}$ \\
\hline $\begin{array}{l}\text { Cordoba } \\
\text { et } \text { al }^{17}\end{array}$ & $\begin{array}{l}120 \mathrm{HCV} \\
40 \text { controls }\end{array}$ & $\begin{array}{l}\text { a. Neuropsychological tests for } \\
\text { learning, attention, processing and } \\
\text { psychomotor speed, language, } \\
\text { executive function, motor skills } \\
\text { b. QOL, depression and anxiety scores }\end{array}$ & $\begin{array}{l}\text { Cognitive impairment in } \\
\text { decompensated cirrhotics only; } \\
\text { QOL not related to cognitive } \\
\text { dysfunction }\end{array}$ & $\begin{array}{l}\text { Patients were identified } \\
\text { through blood donation, } \\
\text { introducing a bias for } \\
\text { good health }\end{array}$ \\
\hline $\begin{array}{l}\text { Fontana } \\
\text { et al }{ }^{18}\end{array}$ & $20 \mathrm{I} \mathrm{HCV}$ & $\begin{array}{l}\text { a. Cognitive tests for learning, } \\
\text { retention, processing speed, } \\
\text { working memory, verbal fluency } \\
\text { b. Depression scores }\end{array}$ & $\begin{array}{l}33 \% \text { cognitive deficits in learning, } \\
\text { working memory, and reaction } \\
\text { times; independent of fibrosis score } \\
\text { and substance use; association of } \\
\text { depression and cognitive impairment }\end{array}$ & $\begin{array}{l}\text { Cohort with advanced } \\
\text { fibrosis and cirrhosis; } \\
\text { high proportion of } \\
\text { alcohol and history of } \\
\text { IVDU }\end{array}$ \\
\hline $\begin{array}{l}\text { Lowry } \\
\text { et } \mathrm{al}^{19}\end{array}$ & $\begin{array}{l}\text { I I female HCV } \\
9 \text { female HCV, } \\
\text { spontaneously cleared }\end{array}$ & $\begin{array}{l}\text { a. Neuropsychological tests for } \\
\text { concentration, learning, working } \\
\text { memory and attention } \\
\text { b. QOL, fatigue and depression scores }\end{array}$ & $\begin{array}{l}\text { PCR-positive women poorer } \\
\text { memory and attention than } \\
\text { PCR-negative and controls }\end{array}$ & $\begin{array}{l}\text { latrogenic infection, } \\
\text { female only cohort }\end{array}$ \\
\hline
\end{tabular}

(Continued) 
Table I (Continued)

\begin{tabular}{|c|c|c|c|c|}
\hline Study & Sample & Measures & Findings & Limitations \\
\hline $\begin{array}{l}\text { Forton } \\
\text { et } \mathrm{al}^{20}\end{array}$ & $\begin{array}{l}25 \mathrm{HCV} \\
18 \mathrm{HCV} \text {-cleared } \\
17 \text { controls }\end{array}$ & $\begin{array}{l}\text { a. 'H MRS } \\
\text { b. Computerised cognitive tests for } \\
\text { attention and working memory }\end{array}$ & $\begin{array}{l}\text { Increased myoinositol (ml) in } \mathrm{HCV} \text {; } \\
\mathrm{HCV} \text {-impaired working memory } \\
\text { and attention; association of } \mathrm{ml} \text { in } \\
\text { frontal white matter and impaired } \\
\text { working memory }\end{array}$ & Small sample \\
\hline $\begin{array}{l}\text { Karaivazoglou } \\
\text { et } \mathrm{al}^{21}\end{array}$ & $\begin{array}{l}32 \mathrm{HCV} \\
29 \mathrm{HBV} \\
20 \text { controls }\end{array}$ & $\begin{array}{l}\text { a. Neuropsychological tests for } \\
\text { verbal fluency, learning, memory, } \\
\text { psychomotor speed, attention, } \\
\text { executive function } \\
\text { b. Depression and fatigue scores }\end{array}$ & $\begin{array}{l}\mathrm{HCV}+\text { impaired on verbal learning } \\
\text { and memory; associated with } \\
\text { fibrosis stage; } \mathrm{HCV}+\text { and } \mathrm{HBV}+ \\
\text { similarly impaired; no association } \\
\text { between depression and cognitive } \\
\text { function }\end{array}$ & At least $22 \%$ cirrhotic \\
\hline
\end{tabular}

Abbreviations: Cho, choline; EEG, electroencephalography; HBV, hepatitis B virus; HCV, hepatitis C virus; IVDU, intravenous drug use; MRS, magnetic resonance spectroscopy; NAA, N-acetyl aspartate; QOL, quality of life; SUD, substance abuse disorder.

was also not observed in patients with chronic hepatitis B infection. Furthermore, elevation in Cho containing compounds is not observed in hepatic encephalopathy, where the $\mathrm{Cho} / \mathrm{Cr}$ ratio is reduced. ${ }^{103}$ These findings suggest that a biological mechanism may underlie the cognitive impairments reported in chronic HCV infection, although a strong association between abnormal cerebral MRS and cognitive impairment was not observed. Weissenborn et al used MRS to study $30 \mathrm{HCV}$-infected patients with normal liver function who had cognitive testing. ${ }^{96}$ They found decreased NAA/Cr ratios in occipital gray matter compared to healthy controls. There were no abnormalities in any other regions or any perturbations in Cho-containing compounds. McAndrews et al used MRS analysis for their cohort of 37 HCV-infected patients with minimal hepatitis. ${ }^{14}$ They found elevations in cerebral Cho and reductions in NAA in voxels that were localized to the central white matter. These findings agree with both the results from Weissenborn's group and from our own center. ${ }^{8,9,96}$ However, none of the studies used the same MR parameters for data acquisition or methods of data analysis, so it is difficult to draw firm conclusions other than to conclude that definable MRS-measurable metabolic abnormalities exist in a proportion of $\mathrm{HCV}$-infected patients with minimal or absent liver disease, who have demonstrated fatigue and cognitive impairment in formalized testing. A feature of all three studies was the absence of a statistical association between cognitive dysfunction and cerebral metabolite ratios. More recently, we showed that elevated frontal white matter $\mathrm{mI} / \mathrm{Cr}$ ratios measured using MRS were significantly associated with deficits in working memory. ${ }^{20}$ Elevations in white and gray matter $\mathrm{mI}$ have also recently been described by Bokemeyer et al. ${ }^{104}$ Similar MRS findings are found in HIV-related minor-cognitive disorder and are considered a marker of immune activation of microglial cells. These findings suggest that, similarly to the CNS effects of
HIV-infection, neuroinflammation may also be a feature in chronic $\mathrm{HCV}$-infection and may underlie the neurocognitive deficits observed in a proportion of patients.

Microglial/brain macrophage activation has also been assessed with PET, using a ligand that binds to the peripheral benziodiazepine receptor (PK11195). Grover et al demonstrated increased ligand binding in the caudate nucleus of HCVinfected patients using PK11195 in a pilot PET study, recruiting patients with histologically mild liver disease. The increased ligand binding, which was positively correlated with $\mathrm{HCV}$ viral load, suggests that neuroinflammation is directly attributable to the viral infection and underlines the potential similarity of neuropathological processes in HIV and HCV infection. ${ }^{101}$ Heeren et al examined the effect of $\mathrm{HCV}$ infection on neurotransmission. ${ }^{105}$ Using a combination of (18)F-fluorodeoxy-glucose PET and single-photon emission computed tomography in 15 patients with minimal liver disease, they demonstrated reduced glucose metabolism in the limbic association cortex as well as in the frontal, parietal, and superior temporal cortices, which correlates with reduced dopamine transporter availability. The authors conclude that alterations in dopaminergic neurotransmission may be an important mechanism of cognitive impairment in $\mathrm{HCV}$ infection.

\section{Changes following successful antiviral therapy for HCV infection}

Data from large HCV treatment studies have demonstrated improved health-related quality of life and reduction in fatigue levels in patients with a sustained virological response (SVR) following pegylated interferon and ribavirin. ${ }^{89}$ Only a limited number of studies have reported the effect of antiviral therapy and, in particular, the effect of successful HCV clearance on cognitive function and brain metabolism.

A recent pilot study ${ }^{106}$ using brain proton MRS and cognitive assessments before, during, and after standard antiviral 
therapy showed significant CNS metabolic changes towards normal levels in patients who had an SVR. These findings were interpreted as improvement in cerebral immune activation associated with HCV clearance. Patients achieving SVR also showed significant improvements in verbal learning, memory, and visuospatial memory, which were not observed in those who were nonresponders to treatment. This study was small and did not include a healthy control group to allow conclusions on the clinical significance of the observed changes and therefore must be validated in a larger sample.

Conversely, another treatment study reported increased rather than decreased basal ganglia $\mathrm{Cho} / \mathrm{Cr}$ and $\mathrm{NAA} / \mathrm{Cr}$ in patients with SVR and no improvement in cognitive measures, ${ }^{107}$ suggesting that viral clearance is not associated with improved cognitive function or cerebral metabolite concentrations observed on MRS. Kraus et al ${ }^{108}$ described impaired reaction times during antiviral therapy with PEG IFN and ribavirin, which were reversed after treatment completion. However, no improvements in cognitive performance were seen after treatment compared to baseline in patients who had cleared HCV or when compared to non-responders.

Reichenberg et al ${ }^{109}$ followed a cohort of $50 \mathrm{HCV}$-infected patients through antiviral therapy and recorded cognitive complaints verbatim before, during, and after treatment. According to their findings, no patients reported cognitive complaints prior to treatment, $30 \%$ complained of cognitive symptoms during antiviral treatment, and 16\% noted cognitive symptoms 8 weeks after completion of treatment. It is unclear how these findings relate to the outcome of antiviral therapy and the fact that no cognitive complaints were recorded at baseline underlines the importance of using objective and sensitive measures of cognitive performance in such studies.

One of the few treatment studies in coinfection by Thein et al $^{110}$ assessed cognitive function during and after antiviral therapy for chronic HCV infection in 19 HCV-monoinfected and $15 \mathrm{HIV} / \mathrm{HCV}$ coinfected patients. Pretreatment cognitive function was similar between the two groups. Six months after completion of antiviral therapy, cognitive performance had improved significantly from baseline in the coinfected group only. Overall, SVR was associated with significant improvement in complex reaction times, but no differences in cognitive performance were seen between the mono- and coinfected groups.

\section{HIV/HCV coinfection}

There has been recent interest in the possibility that HCV may contribute to CNS dysfunction in HIV-infected individuals. Similar frontosubcortical patterns of neurocognitive impairment have been described in HIV and HCV infection ${ }^{111}$ for deficits in complex attention/concentration, information processing, and psychomotor speed.

Several studies have now documented greater neurocognitive impairment in coinfected patients on measures of executive and overall cognitive functioning, while a smaller number of studies failed to show any additional impact of HCV infection on cognitive dysfunction in HIV-infected subjects. The relevant studies published in this field are summarized in Table 2 . They primarily include small cohort studies which have applied variable degrees of stringency in controlling for confounding factors such as severity of liver disease, duration of infection, or types of cART regimen. ${ }^{23,24,112}$ Liver fibrosis progresses more rapidly in $\mathrm{HIV} / \mathrm{HCV}$ coinfection and an assessment of cirrhosis is necessary to exclude MHE.

Aronow et $\mathrm{al}^{22}$ studied a cohort of patients with late-stage HIV disease to determine whether coinfection with HCV was associated with increased prevalence and severity of cognitive impairment; of 159 persons with late-stage HIV-infection, 31 tested positive for $\mathrm{HCV}$ and were compared to 31 randomly selected HIV monoinfected subjects from the same cohort. $\mathrm{HIV} / \mathrm{HCV}$-coinfected subjects showed greater, statistically significant neurocognitive impairment on a composite scoring system derived from neurological and neurophysiological assessment compared with HIV monoinfection. There were no statistically significant differences between the groups on the neuropsychological battery.

Two published studies from the Manhattan HIV Brain Bank cohort ${ }^{25,26}$ enrolled HIV positive subjects with advanced HIV and applied a broad range of neuropsychological tests to a group of $67 \mathrm{HIV} / \mathrm{HCV}$-coinfected patients and a group of 49 well-matched HIV monoinfected patients. High levels of cognitive impairment were reported across all measured domains in both groups. Coinfected patients were more impaired in executive functioning and more likely to meet diagnostic criteria for AIDS dementia. The authors concluded that there was a detectable impact of HCV coinfection on neurocognitive functioning, despite the advanced stage of HIV disease of their cohort. No association between the indices of liver disease (MELD score) and cognitive deficits was seen in this cohort. Conversely, the HCV-negative group was more likely to be diagnosed with minor cognitive motor dysfunction. These studies only used biochemical parameters to assess liver disease, which do not reliably detect cirrhosis. Furthermore, only serological tests were used to diagnose $\mathrm{HCV}$ infection, and subjects with cleared infection may have been included. 
Table 2 Studies of cognitive function in HIV/HCV coinfected cohorts

\begin{tabular}{|c|c|c|c|c|}
\hline Study & Sample & Measures & Findings & Limitations \\
\hline Aronow et $\mathrm{al}^{22}$ & $\begin{array}{l}\text { 3I HIV/HCV coinfected } \\
\text { 3I HIV monoinfected }\end{array}$ & $\begin{array}{l}\text { a. Neuropsychological test } \\
\text { battery for verbal fluency, } \\
\text { learning, information } \\
\text { processing, memory, executive } \\
\text { function, attention, working } \\
\text { memory, and motor skills } \\
\text { b. Neurological and } \\
\text { neuropsychological assessment }\end{array}$ & $\begin{array}{l}\text { No significant difference on } \\
\text { cognitive testing battery; composite } \\
\text { clinical neuropsychological } \\
\text { assessment suggested significant } \\
\text { impairment in coinfected group }\end{array}$ & $\begin{array}{l}\text { No assessment of liver } \\
\text { disease }\end{array}$ \\
\hline Parsons et $\mathrm{al}^{23}$ & $\begin{array}{l}45 \mathrm{HIV} \text { monoinfected } \\
20 \mathrm{HIV} / \mathrm{HCV} \text { coinfected }\end{array}$ & $\begin{array}{l}\text { Prospective study before } \\
\text { and after HAART initiation; } \\
\text { neuropsychological tests for } \\
\text { attention, psychomotor speed, } \\
\text { executive functioning, verbal and } \\
\text { visual memory, motor function }\end{array}$ & $\begin{array}{l}\text { Significantly worse visual memory } \\
\text { and fine motor function in } \\
\text { coinfected group; improved } \\
\text { after HAART }\end{array}$ & $\begin{array}{l}\text { Not controlled for liver } \\
\text { disease }\end{array}$ \\
\hline Letendre et $\mathrm{al}^{24}$ & $\begin{array}{l}239 \mathrm{HIV}+ \\
287 \mathrm{HIV}_{-} \\
21 \% \mathrm{HCV}+\end{array}$ & $\begin{array}{l}\text { Neuropsychological tests for } \\
\text { verbal fluency, attention, } \\
\text { working memory, speed of } \\
\text { processing, learning, recall, } \\
\text { problem solving, motor ability }\end{array}$ & $\begin{array}{l}\text { Worse performance in } \mathrm{HCV}+ \\
\text { group, controlled for HIV-infection } \\
\text { and methamphetamine dependence; } \\
\text { higher HCV RNA levels associated } \\
\text { with memory impairment }\end{array}$ & $\begin{array}{l}\text { No formal assessment } \\
\text { of liver disease }\end{array}$ \\
\hline $\begin{array}{l}\text { Ryan et } \mathrm{al}^{25} \text { and } \\
\text { Morgello et } \mathrm{al}^{26}\end{array}$ & $\begin{array}{l}67 \mathrm{HIV}+/ \mathrm{HCV}_{+} \\
49 \mathrm{HIV}+/ \mathrm{HCV}_{-}\end{array}$ & $\begin{array}{l}\text { a. Neuropsychological test } \\
\text { battery for psychomotor } \\
\text { speed, attention, verbal } \\
\text { fluency, executive function } \\
\text { b. Indices of liver disease - MELD }\end{array}$ & $\begin{array}{l}\text { Coinfected patients greater rate } \\
\text { of impairment on executive function } \\
\text { and more likely to be diagnosed } \\
\text { with HAD; no relationship between } \\
\text { MELD and cognitive deficits }\end{array}$ & $\begin{array}{l}\text { Not controlled for } \\
\text { cirrhosis }\end{array}$ \\
\hline Hilsabeck et $\mathrm{al}^{27}$ & $\begin{array}{l}\text { I } 70 \text { HIV monoinfected } \\
25 \mathrm{HIV} / \mathrm{HCV} \text { coinfected }\end{array}$ & $\begin{array}{l}\text { Neuropsychological test battery } \\
\text { for psychomotor speed, learning } \\
\text { and memory, attention, } \\
\text { executive function, } \\
\text { verbal fluency, motor speed }\end{array}$ & $\begin{array}{l}80 \% \text { of coinfected versus } 69 \% \text { of } \\
\text { monoinfected group cognitively } \\
\text { impaired; } 84 \% \text { of coinfected } \\
\text { versus } 56 \% \text { of monoinfected } \\
\text { demonstrated significant } \\
\text { psychomotor slowing }(P<0.007)\end{array}$ & $\begin{array}{l}\text { No assessment of liver } \\
\text { disease; coinfected cohort } \\
\text { contained more current } \\
\text { and past drug and alcohol } \\
\text { use }\end{array}$ \\
\hline Martin et $\mathrm{al}^{28}$ & $\begin{array}{l}28 \mathrm{HIV} / \mathrm{HCV} \text { coinfected } \\
39 \mathrm{HIV} \text { monoinfected } \\
69 \mathrm{HIV}-/ \mathrm{HCV}-\text { controls } \\
20 \mathrm{HIV}-/ \mathrm{HCV}+\end{array}$ & $\begin{array}{l}\text { Voice-activated version of Stroop } \\
\text { task (executive function) }\end{array}$ & $\begin{array}{l}\text { Significant cognitive dysfunction } \\
\text { in HIV and HCV monoinfected } \\
\text { individuals; coinfected subjects } \\
\text { more impaired than monoinfected }\end{array}$ & Liver disease not assessed \\
\hline Clifford et $\mathrm{al}^{30}$ & $\begin{array}{l}\text { I } 72 \text { HIV/HCV coinfected } \\
345 \text { HIV monoinfected }\end{array}$ & $\begin{array}{l}\text { Brief neuropsychological tests } \\
\text { for sustained attention, response } \\
\text { speed, visuomotor coordination }\end{array}$ & $\begin{array}{l}\text { Both groups performed slightly } \\
\text { below norm; group difference seen } \\
\text { for HCV exposure but not viremia }\end{array}$ & $\begin{array}{l}\text { Limited } \\
\text { neuropsychological } \\
\text { battery }\end{array}$ \\
\hline Hinkin et $\mathrm{al}^{29}$ & $\begin{array}{l}85 \mathrm{HIV} \text { monoinfected } \\
35 \mathrm{HIV} / \mathrm{HCV} \text { coinfected }\end{array}$ & $\begin{array}{l}\text { Neuropsychological test battery } \\
\text { for attention/working memory, } \\
\text { information processing, learning, } \\
\text { memory, verbal fluency, executive } \\
\text { function, psychomotor speed }\end{array}$ & $\begin{array}{l}63 \% \text { in coinfected versus } 43 \% \text { in } \\
\text { HIV monoinfected group globally } \\
\text { impaired }(P=0.05) \text {; predominantly } \\
\text { impaired learning and memory }\end{array}$ & Liver disease not assessed \\
\hline von Giesen et $\mathrm{al}^{31}$ & $\begin{array}{l}43 \mathrm{HIV} / \mathrm{HCV} \text { coinfected } \\
43 \mathrm{HIV} \text { monoinfected } \\
44 \mathrm{HCV} \text { monoinfected }\end{array}$ & $\begin{array}{l}\text { a. Brief neuropsychological testing } \\
\text { b. Electrophysiological } \\
\text { assessment of basal ganglia- } \\
\text { mediated motor function }\end{array}$ & $\begin{array}{l}\text { No significant group differences } \\
\text { in cognitive tasks; impaired } \\
\text { psychomotor speed in all } 3 \text { groups }\end{array}$ & No HIV-/HCV- controls \\
\hline Perry et $\mathrm{al}^{32}$ & $\begin{array}{l}29 \mathrm{HIV} / \mathrm{HCV} \text { coinfected } \\
47 \mathrm{HCV} \text { monoinfected }\end{array}$ & $\begin{array}{l}\text { Neuropsychological test battery } \\
\text { for attention, concentration, } \\
\text { psychomotor speed }\end{array}$ & $\begin{array}{l}\text { No differences between the } \\
2 \text { groups; liver fibrosis stage } \\
\text { associated with cognitive test } \\
\text { performance }\end{array}$ & $\begin{array}{l}\text { More patients with } \\
\text { cirrhosis in HCV group }\end{array}$ \\
\hline Soogoor et $\mathrm{al}^{33}$ & $\begin{array}{l}70 \mathrm{HIV}-/ \mathrm{HCV}- \\
103 \text { HIV-/HCV+ } \\
199 \mathrm{HIV}+/ \mathrm{HCV}+ \\
\text { Hemophiliac children } \\
\text { and teenagers }\end{array}$ & $\begin{array}{l}\text { Age-appropriate measures of } \\
\text { aspects of adaptive behavior, } \\
\text { general intelligence, attention/ } \\
\text { concentration, expressive } \\
\text { vocabulary, and visual-spatial } \\
\text { construction }\end{array}$ & $\begin{array}{l}\text { No detrimental effect of } \mathrm{HCV} \\
\text { infection documented }\end{array}$ & $\begin{array}{l}\text { Pediatric/adolescent } \\
\text { cohort; relatively short } \\
\text { duration of infection; } \\
\text { no assessment of liver } \\
\text { disease }\end{array}$ \\
\hline
\end{tabular}

Abbreviations: HCV, hepatitis C virus; HAART, highly active antiretroviral therapy; HAD, HIV-associated dementia; HIV, human immunodeficiency virus; MELD, indices of liver disease. 
Hilsabeck et al studied a cohort of 195 HIV-infected individuals, of which 25 were HCV-coinfected. Eighty percent of the coinfected group was classified as neurocognitively impaired, compared to $69 \%$ of the HIV-monoinfected group. ${ }^{27}$ This difference was largely due to psychomotor slowing in the coinfected patients, while there were no significant differences between groups in the other cognitive domains tested. Importantly, coinfected patients had a significantly higher rate of previous alcohol dependence and drug use, both of which may impact on cognitive performance. The degree of underlying liver disease was also not controlled in this study.

Letendre et a ${ }^{24}$ performed a cross-sectional analysis of a cohort of 526 prospectively recruited subjects, of which 239 were HIV-infected; they considered the impact of $\mathrm{HCV}$ infection and methamphetamine use. A total of $21 \%$ of the cohort were $\mathrm{HCV}$-infected. $\mathrm{HCV}$-infected subjects performed worse on neurocognitive assessment, independent of HIVstatus and metamphetamine use. Multivariate analysis showed that HIV, HCV, and metamphetamine use were independently associated with worse cognitive performance. Higher plasma HCV RNA levels were associated with impaired memory, supporting a link between viral replication and brain injury.

Martin et $\mathrm{a}^{28}$ identified an additive effect of coinfection over mono-infection with either virus only on cognitive function in 156 drug users with known HIV and HCV serostatus. This study applied a voice-activated reaction time version of the Stroop task sensitive to HIV-associated cognitive dysfunction to 28 coinfected, $39 \mathrm{HIV}+/ \mathrm{HCV}_{-}$, $69 \mathrm{HIV}-/ \mathrm{HCV}_{-}$, and $20 \mathrm{HIV}-/ \mathrm{HCV}+$ subjects. The HCV+ subjects reacted more slowly than the $\mathrm{HCV}$ - subjects, regardless of HIV status, although the difference fell just short of statistical significance. Significant impairment in the incongruent task of the Stroop test was seen in HIV+ individuals, suggestive of impaired executive function, while the authors concluded that $\mathrm{HCV}$-infection may cause slowed information processing. Overall, Stroop performance demonstrated worse cognitive performance in monoinfected subjects compared to seronegative controls and in turn further impairment in coinfected compared to monoinfected subjects. This study, however, did not control for cirrhosis, and there is a possibility that the additional effect of $\mathrm{HCV}$ infection on cognitive performance may be mediated by MHE and not solely through a CNS effect of HCV. A number of other studies which identified positive associations between $\mathrm{HIV} / \mathrm{HCV}$ coinfection and neurocognitive impairment are described in Table 2.
In contrast to these findings, which suggest increased neurocognitive impairment in coinfected patients, a retrospective study from the AIDS Clinical Trials Group Longitudinal Linked Randomized Trials (ALLRT) found that active $\mathrm{HCV}$ infection did not exacerbate clinically significant neurocognitive dysfunction or peripheral neuropathy in individuals with controlled HIV infection. ${ }^{30}$

Interestingly, when $\mathrm{HCV}$ antibody status was considered rather than HCV RNA status, a marginally significant difference in performance favoring the HCV antibody negative group emerged. This suggests that a history of infection by HCV reflected in the antibody status is more important than the contribution of $\mathrm{HCV}$ replication when cognitive performance is measured.

There has been recent interest in the possibility that acute HCV infection in HIV-infected individuals may affect the brain. The increased detection of acute HCV infection, predominantly amongst HIV-positive gay men who engage in high-risk sexual practices, ${ }^{113}$ has allowed this to be studied. Ten HIV patients with documented acute HCV infection (HCV RNA-positive and HCV antibody-negative) were reported to have reduced basal ganglia $\mathrm{mI} / \mathrm{Cr}$ ratios according to MRS ${ }^{114}$ and impaired cognitive function when compared to an HIV-monoinfected and a normal control group.

In summary, there are reports in the literature that support an association of $\mathrm{HCV}$ infection with increased cognitive impairment in HIV infection. However, whether this is due to the hepatitis $\mathrm{C}$ virus itself or associated non-virological factors remains to be determined. The increased rates of impairment in these coinfected cohorts are associated with higher rates of historical drug abuse. Most studies have not controlled appropriately for the degree of underlying liver fibrosis/cirrhosis, and therefore subclinical MHE, associated with the greater probability of more advanced liver disease in coinfected patients, may have impacted on cognitive performance measures. Ultimately, prospective studies assessing the long-term effects on cognitive function of $\mathrm{HCV}$ eradication in coinfection are warranted.

\section{Conclusion}

Although the neurocognitive consequences of HCV infection in monoinfection or coinfection have not been completely defined, imaging evidence suggests a biological effect on the CNS, raising the possibility of $\mathrm{HCV}$ penetration into the brain.

HCV RNA has been detected in postmortem brain samples and CSF using PCR-based methods, but this does not prove 
infection or replication due to blood contamination. ${ }^{115-118}$ HCV RNA quantitation suggests a 1000-10,000-fold lower level in brain compared to liver, suggesting the brain as a minor replication site. ${ }^{117}$ Nevertheless, detection of the negative strand of HCV RNA, which is considered a replicative intermediate, ${ }^{116}$ and distinct viral quasispecies within brain samples of $\mathrm{HCV}$-infected subjects, ${ }^{116-118}$ are consistent with $\mathrm{HCV}$ replication within the CNS, albeit at a low level. Sequences incorporating the HCV internal ribosomal entry site were detected in the CNS and, when incorporated into a reporter vector, resulted in reduced translational efficiency, which may represent a possible mechanism for CNS latency. ${ }^{118}$

The cell type that may harbor HCV within the CNS has been a subject of debate. Immunohistochemical and molecular approaches have suggested that microglia and astrocytes are candidate cells. ${ }^{119,120}$ Wilkinson et al showed that cells that stained for HCV nonstructural protein 3 also costained for CD68, consistent with microglia. When these cells were microdissected and pooled for RNA expression studies, there was expression of microglial markers as well as increased proinflammatory genes such as $T N F-\alpha$ and $I L-12 .{ }^{120}$ These findings were not evident in $\mathrm{HCV}$ - patients or in microdissected cells from $\mathrm{HCV}+$ patients that did not stain for nonstructural protein 3 . These studies, which include HCV-monoinfected and HIV/HCV-coinfected patients, are consistent with microglial immune activation as a consequence of $\mathrm{HCV}$ infection and parallel findings from the clinical PET study using PK11195. ${ }^{101}$

Astroglia do not express cell molecules required for classical HCV entry (tetraspanin, CD81, and tight junction proteins claudin-1 and occludin), ${ }^{121}$ and attention has turned to other CNS cell lineages. After demonstrating that two independent neurepthelioma cell lines expressed these molecules and supported viral entry and replication, ${ }^{121,122}$ Fletcher et al showed that brain microvascular endothelial cells (BMECs), the major component of the blood-brain barrier, support $\mathrm{HCV}$ infection in culture. ${ }^{123}$ In a series of elegant experiments, they showed that BMECs were permissive for cell culture-derived $\mathrm{HCV}$, showing a spreading infection and release of particles that were subsequently infectious for Huh-7 hepatoma cells; this was the first demonstration of $\mathrm{HCV}$ replication in non-hepatocyte cell culture. Infected BMECs displayed apoptosis and reduced endothelial barrier activity, leading the authors to propose that HCV may disrupt blood-brain barrier integrity, allowing influx of peripheral cytokines, viruses, and immune cells. In this way, HCV may result in an altered immune environment within the CNS to potentiate the effects of HIV infection. Furthermore, there may be interactions between viral proteins that potentiate neurotoxicity, as suggested in a recent report in which HCV core protein potentiated HIV-1 neurotoxicity in a mouse model. ${ }^{124}$

The clinical evidence for neurocognitive impairment in HCV monoinfection and HIV coinfection has aroused interest, but the clinical significance in terms of disease endpoints remains to be defined. Emerging mechanisms that have been studied as a consequence of the clinical observations may have a greater significance in terms of antiviral therapy than the definition of the clinical phenotype itself. HCV therapy is changing rapidly, with interferon-free combinations of directly acting antiviral drugs in clinical development. Little is known regarding the brain parenchymal penetration of these agents or of the efficiency of drug efflux mechanisms at the blood-brain barrier. It will be of great interest to see whether these new treatment regimens reverse cognitive impairments in $\mathrm{HCV}$ monoinfection and coinfection or whether neurocognitive impairments may persist as in the cART treatment of HIV infection. ${ }^{125}$ Finally, the impact of an immune-privileged, extrahepatic site for $\mathrm{HCV}$ replication may have implications for late relapse after oral antiviral therapy.

\section{Disclosure}

The authors report no conflicts of interest in this work.

\section{References}

1. UNAIDS. Epidemic update. In: Global Report: UNAIDS Report on the Global AIDS Epidemic 2010. Joint United Nations Programme on HIV/ AIDS (UNAIDS); 2010. Available from: www.unaids.org/en/media/ unaids/contentassets/documents/unaidspublication/2010/20101123_ globalreport_en.pdf. Accessed October 15, 2012.

2. World Health Organization. Hepatitis C: fact sheet, no. 164. Geneva: World Health Organization; 2012. Available from: http://www.who. int/mediacentre/factsheets/fs164/en/index.html. Accessed October $15,2012$.

3. Verucchi G, Calza L, Manfredi R, Chiodo F. Human immunodeficiency virus and hepatitis $\mathrm{C}$ virus coinfection: epidemiology, natural history, therapeutic options and clinical management. Infection. 2004; 32(1):33-46.

4. Hestad K, McArthur JH, Dal Pan GJ, et al. Regional brain atrophy in HIV-1 infection: association with specific neuropsychological test performance. Acta Neurol Scand. 1993;88(2):112-118.

5. Hinkin $\mathrm{CH}$, van Gorp WG, Mandelkern MA, et al. Cerebral metabolic change in patients with AIDS: Report of a six-month follow-up using positron-emission tomography. J Neuropsychiatry Clin Neurosci. 1995; $7(2): 180-187$

6. Navia BA, Jordan BD, Price RW. The AIDS dementia complex: I. Clinical features. Ann Neurol. 1986;19(6):517-524.

7. Navia BA, Cho ES, Petito CK, Price RW. The AIDS dementia complex: II. Neuropathology. Ann Neurol. 1986;19(6):525-535.

8. Forton DM,Allsop JM, Main J, Foster GR, Thomas HC, Taylor-Robinson SD. Evidence for a cerebral effect of the hepatitis C virus. Lancet. 2001; 358(9275):38-39. 
9. Forton DM, Thomas HC, Murphy CA, et al. Hepatitis C and cognitive impairment in a cohort of patients with mild liver disease. Hepatology. 2002;35(2):433-439.

10. Weissenborn K, Krause J, Bokemeyer M, et al. Hepatitis C virus infection affects the brain-evidence from psychometric studies and magnetic resonance spectroscopy. J Hepatol. 2004;41(5):845-851.

11. Hilsabeck RC, Hassanein TI, Carlson MD, Ziegler EA, Perry W. Cognitive functioning and psychiatric symptomatology in patients with chronic hepatitis C. J Int Neuropsychol Soc. 2003;9(6):847-854.

12. Hilsabeck RC, Perry W, Hassanein TI. Neuropsychological impairment in patients with chronic hepatitis C. Hepatology. 2002;35(2):440-446.

13. Kramer L, Bauer E, Funk G, et al. Subclinical impairment of brain function in chronic hepatitis C infection. J Hepatol. 2002;37(3): 349-354.

14. McAndrews MP, Farcnik K, Carlen P, et al. Prevalence and significance of neurocognitive dysfunction in hepatitis $\mathrm{C}$ in the absence of correlated risk factors. Hepatology. 2005;41(4):801-808.

15. Huckans M, Seelye A, Parcel T, et al. The cognitive effects of hepatitis $\mathrm{C}$ in the presence and absence of a history of substance use disorder. J Int Neuropsychol Soc. 2009;15(1):69-82.

16. Kramer L, Hofer H, Bauer E, et al. Relative impact of fatigue and subclinical cognitive brain dysfunction on health-related quality of life in chronic hepatitis C infection. AIDS. 2005;19 Suppl 3:S85-S92.

17. Cordoba J, Flavia M, Jacas C, et al. Quality of life and cognitive function in hepatitis C at different stages of liver disease. J Hepatol. 2003; 39(2):231-238.

18. Fontana RJ, Bieliauskas LA, Back-Madruga C, et al. Cognitive function in hepatitis $\mathrm{C}$ patients with advanced fibrosis enrolled in the HALT-C trial. J Hepatol. 2005;43(4):614-622.

19. Lowry D, Coughlan B, McCarthy O, Crowe J. Investigating healthrelated quality of life, mood and neuropsychological test performance in a homogeneous cohort of Irish female hepatitis C patients. J Viral Hepat. 2010;17(5):352-359.

20. Forton DM, Hamilton G, Allsop JM, et al. Cerebral immune activation in chronic hepatitis $\mathrm{C}$ infection: A magnetic resonance spectroscopy study. J Hepatol. 2008;49(3):316-322.

21. Karaivazoglou K, Assimakopoulos K, Thomopoulos K, et al. Neuropsychological function in Greek patients with chronic hepatitis C. Liver Int. 2007;27(6):798-805.

22. Aronow HA, Weston AJ, Pezeshki BB, Lazarus TS. Effects of coinfection with HIV and hepatitis $\mathrm{C}$ virus on the nervous system. AIDS Read. 2008;18(1):43-48.

23. Parsons TD, Tucker KA, Hall CD, et al. Neurocognitive functioning and HAART in HIV and hepatitis $\mathrm{C}$ virus co-infection. AIDS. 2006;20(12):1591-1595.

24. Letendre SL, Cherner M, Ellis RJ, et al. The effects of hepatitis C, HIV, and methamphetamine dependence on neuropsychological performance: biological correlates of disease. AIDS. 2005;19 Suppl 3: S72-S78.

25. Ryan EL, Morgello S, Isaacs K, Naseer M, Gerits P; Manhattan HIV Brain Bank. Neuropsychiatric impact of hepatitis $\mathrm{C}$ on advanced HIV. Neurology. 2004;62(6):957-962.

26. Morgello S, Estanislao L, Ryan E, et al. Effects of hepatic function and hepatitis $\mathrm{C}$ virus on the nervous system assessment of advanced-stage HIV-infected individuals. AIDS. 2005;19 Suppl 3:S116-S122.

27. Hilsabeck RC, Castellon SA, Hinkin CH. Neuropsychological aspects of coinfection with HIV and hepatitis C virus. Clin Infect Dis. 2005; 41 Suppl 1:S38-S44.

28. Martin EM, Novak RM, Fendrich M, et al. Stroop performance in drug users classified by HIV and hepatitis C virus serostatus. J Int Neuropsychol Soc. 2004;10(2):298-300.

29. Hinkin $\mathrm{CH}$, Castellon SA, Levine AJ, Barclay TR, Singer EJ. Neurocognition in individuals co-infected with HIV and hepatitis C. $J$ Addict Dis. 2008;27(2):11-17.

30. Clifford DB, Smurzynski M, Park LS, et al. Effects of active HCV replication on neurologic status in HIV RNA virally suppressed patients. Neurology. 2009;73(4):309-314.
31. von Giesen HJ, Heintges T, Abbasi-Boroudjeni N, et al. Psychomotor slowing in hepatitis C and HIV infection. J Acquir Immune Defic Syndr. 2004;35(2):131-137.

32. Perry W, Carlson MD, Barakat F, et al. Neuropsychological test performance in patients co-infected with hepatitis $\mathrm{C}$ virus and HIV. AIDS. 2005;19 Suppl 3:S79-S84.

33. Soogoor M, Lynn HS, Donfield SM, et al. Hepatitis C virus infection and neurocognitive function. Neurology. 2006;67(8):1482-1485.

34. Anthony IC, Bell JE. The neuropathology of HIV/AIDS. Int Rev Psychiatry. 2008;20(1):15-24.

35. McArthur JC, Brew BJ, Nath A. Neurological complications of HIV infection. Lancet Neurol. 2005;4(9):543-555.

36. Simioni S, Cavassini M, Annoni JM, et al. Cognitive dysfunction in HIV patients despite long-standing suppression of viremia. AIDS. 2010;24(9):1243-1250.

37. Antinori A, Arendt G, Becker JT, et al. Updated research nosology for HIV-associated neurocognitive disorders. Neurology. 2007;69(18): 1789-1799.

38. Hazleton JE, Berman JW, Eugenin EA. Novel mechanisms of central nervous system damage in HIV infection. HIV AIDS (Auckl). 2010;2: 39-49.

39. Ellis R, Langford D, Masliah E. HIV and antiretroviral therapy in the brain: Neuronal injury and repair. Nat Rev Neurosci. 2007;8(1):33-44.

40. Heaton RK, Grant I, Butters N, et al. The HNRC 500 - neuropsychology of HIV infection at different disease stages. HIV Neurobehavioral Research Center. J Int Neuropsychol Soc. 1995;1(3):231-251.

41. Stout JC, Salmon DP, Butters N, et al. Decline in working memory associated with HIV infection. HNRC group. Psychol Med. 1995;25(6): 1221-1232.

42. Marcotte TD, Grant I, Atkinson JH, Heaton RK. Neurobehavioral complications of HIV infection. In: Butters M, Beers SR, editors. Medical Neuropsychology. New York: Kluwer Academic/Plenum Publishers; 2001:85-105.

43. Nomenclature and research case definitions for neurologic manifestations of human immunodeficiency virus-type 1 (HIV-1) infection. Report of a working group of the American Academy of Neurology AIDS Task Force. Neurology. 1991;41(6):778-785.

44. Post MJ, Berger JR, Duncan R, Quencer RM, Pall L, Winfield D. Asymptomatic and neurologically symptomatic HIV-seropositive subjects: results of long-term MR imaging and clinical follow-up. Radiology. 1993;188(3):727-733.

45. Broderick DF, Wippold FJ 2nd, Clifford DB, Kido D, Wilson BS. White matter lesions and cerebral atrophy on MR images in patients with and without AIDS dementia complex. AJR Am J Roentgenol. 1993;161(1): 177-181.

46. Stout JC, Ellis RJ, Jernigan TL, et al. Progressive cerebral volume loss in human immunodeficiency virus infection: a longitudinal volumetric magnetic resonance imaging study. HIV neurobehavioral research center group. Arch Neurol. 1998;55(2):161-168.

47. Samuelsson K, Pirskanen-Matell R, Bremmer S, Hindmarsh T, Nilsson BY, Persson HE. The nervous system in early HIV infection: a prospective study through 7 years. Eur J Neurol. 2006;13(3): 283-291.

48. Marcus CD, Taylor-Robinson SD, Sargentoni J, et al. 1H MR spectroscopy of the brain in HIV-1-seropositive subjects: evidence for diffuse metabolic abnormalities. Metab Brain Dis. 1998;13(2):123-136.

49. Meyerhoff DJ, Bloomer C, Cardenas V, Norman D, Weiner MW, Fein G. Elevated subcortical choline metabolites in cognitively and clinically asymptomatic HIV+ patients. Neurology. 1999;52(5):995-1003.

50. Chang L, Ernst T, Leonido-Yee M, Walot I, Singer E. Cerebral metabolite abnormalities correlate with clinical severity of HIV-1 cognitive motor complex. Neurology. 1999;52(1):100-108.

51. Stankoff B, Tourbah A, Suarez S, et al. Clinical and spectroscopic improvement in HIV-associated cognitive impairment. Neurology. 2001;56(1):112-115.

52. Bell JE. An update on the neuropathology of HIV in the HAART era. Histopathology. 2004;45(6):549-559. 
53. Bell JE. The neuropathology of adult HIV infection. Rev Neurol (Paris). 1998;154(12):816-829.

54. Gray F, Scaravilli F, Everall I, et al. Neuropathology of early HIV-1 infection. Brain Pathol. 1996;6(1):1-15.

55. Sinclair E, Gray F, Ciardi A, Scaravilli F. Immunohistochemical changes and PCR detection of HIV provirus DNA in brains of asymptomatic HIV-positive patients. J Neuropathol Exp Neurol. 1994;53(1):43-50.

56. Everall I, Vaida F, Khanlou N, et al. Cliniconeuropathologic correlates of human immunodeficiency virus in the era of antiretroviral therapy. J Neurovirol. 2009;15(5-6):360-370.

57. Ranki A, Nyberg M, Ovod V, et al. Abundant expression of HIV nef and rev proteins in brain astrocytes in vivo is associated with dementia. AIDS. 1995;9(9):1001-1008.

58. Trillo-Pazos G, Diamanturos A, Rislove L, et al. Detection of HIV-1 DNA in microglia/macrophages, astrocytes and neurons isolated from brain tissue with HIV-1 encephalitis by laser capture microdissection. Brain Pathol. 2003;13(2):144-154.

59. Esiri MM, Morris CS, Millard PR. Fate of oligodendrocytes in HIV-1 infection. AIDS. 1991;5(9):1081-1088.

60. Anderson E, Zink W, Xiong H, Gendelman HE. HIV-1-associated dementia: A metabolic encephalopathy perpetrated by virus-infected and immune-competent mononuclear phagocytes. J Acquir Immune Defic Syndr. 2002;31 Suppl 2:S43-S54.

61. Lambotte O, Deiva K, Tardieu M. HIV-1 persistence, viral reservoir, and the central nervous system in the HAART era. Brain Pathol. 2003;13(1):95-103.

62. Albright AV, Soldan SS, Gonzalez-Scarano F. Pathogenesis of human immunodeficiency virus-induced neurological disease. $J$ Neurovirol. 2003;9(2):222-227.

63. Kaul M, Lipton SA. Chemokines and activated macrophages in HIV gp120-induced neuronal apoptosis. Proc Natl Acad Sci U S A. 1999; 96(14):8212-8216.

64. Johnston JB, Zhang K, Silva C, et al. HIV-1 tat neurotoxicity is prevented by matrix metalloproteinase inhibitors. Ann Neurol. 2001;49(2): 230-241.

65. Power C, McArthur JC, Nath A, et al. Neuronal death induced by brain-derived human immunodeficiency virus type 1 envelope genes differs between demented and nondemented AIDS patients. $J$ Virol. 1998;72(11):9045-9053.

66. Pu H, Tian J, Flora G, et al. HIV-1 tat protein upregulates inflammatory mediators and induces monocyte invasion into the brain. Mol Cell Neurosci. 2003;24(1):224-237.

67. Wong JK, Ignacio CC, Torriani F, Havlir D, Fitch NJ, Richman DD In vivo compartmentalization of human immunodeficiency virus: Evidence from the examination of pol sequences from autopsy tissues. J Virol. 1997;71(3):2059-2071.

68. Dunfee R, Thomas ER, Gorry PR, Wang J, Ancuta P, Gabuzda D. Mechanisms of HIV-1 neurotropism. Curr HIV Res. 2006;4(3): 267-278.

69. Dunfee RL, Thomas ER, Gorry PR, et al. The HIV env variant N283 enhances macrophage tropism and is associated with brain infection and dementia. Proc Natl Acad Sci U S A. 2006;103(41):15160-15165.

70. Sacktor N, Lyles RH, Skolasky R, et al. HIV-associated neurologic disease incidence changes: multicenter AIDS cohort study, 1990-1998. Neurology. 2001;56(2):257-260.

71. Dore GJ, Correll PK, Li Y, Kaldor JM, Cooper DA, Brew BJ. Changes to AIDS dementia complex in the era of highly active antiretroviral therapy. AIDS. 1999;13(10):1249-1253.

72. Tozzi V, Balestra P, Bellagamba R, et al. Persistence of neuropsychologic deficits despite long-term highly active antiretroviral therapy in patients with HIV-related neurocognitive impairment: prevalence and risk factors. J Acquir Immune Defic Syndr. 2007;45(2): 174-182.

73. Larussa D, Lorenzini P, Cingolani A, et al. Highly active antiretroviral therapy reduces the age-associated risk of dementia in a cohort of older HIV-1-infected patients. AIDS Res Hum Retroviruses. 2006;22(5):386-392.
74. Woods SP, Moore DJ, Weber E, Grant I. Cognitive neuropsychology of HIV-associated neurocognitive disorders. Neuropsychol Rev. 2009;19(2):152-168.

75. Robertson KR, Smurzynski M, Parsons TD, et al. The prevalence and incidence of neurocognitive impairment in the HAART era. AIDS. 2007;21(14):1915-1921.

76. Cysique LA, Maruff P, Brew BJ. Prevalence and pattern of neuropsychological impairment in human immunodeficiency virus-infected/ acquired immunodeficiency syndrome (HIV/AIDS) patients across pre- and post-highly active antiretroviral therapy eras: a combined study of two cohorts. J Neurovirol. 2004;10(6):350-357.

77. McArthur JC. HIV dementia: an evolving disease. J Neuroimmunol. 2004;157(1-2):3-10.

78. Antiretroviral Therapy Cohort Collaboration. Life expectancy of individuals on combination antiretroviral therapy in high-income countries: a collaborative analysis of 14 cohort studies. Lancet. 2008;372(9635): 293-299.

79. Dougherty RH, Skolasky RL Jr, McArthur JC. Progression of HIVassociated dementia treated with HAART. AIDS Read. 2002;12(2):69-74.

80. Ciccarelli N, Fabbiani M, Di Giambenedetto S, et al. Efavirenz associated with cognitive disorders in otherwise asymptomatic HIV-infected patients. Neurology. 2011;76(16):1403-1409.

81. Cysique LA, Brew BJ. Neuropsychological functioning and antiretroviral treatment in HIV/AIDS: a review. Neuropsychol Rev. 2009;19(2):169-185.

82. Venkataramana A, Pardo CA, McArthur JC, et al. Immune reconstitution inflammatory syndrome in the CNS of HIV-infected patients. Neurology. 2006;67(3):383-388.

83. Gray F, Bazille C, Adle-Biassette H, Mikol J, Moulignier A, Scaravilli F. Central nervous system immune reconstitution disease in acquired immunodeficiency syndrome patients receiving highly active antiretroviral treatment. J Neurovirol. 2005;11 Suppl 3:16-22.

84. Poynard T, Cacoub P, Ratziu V, et al. Fatigue in patients with chronic hepatitis C. J Viral Hepat. 2002;9(4):295-303.

85. Wessely S, Pariante C. Fatigue, depression and chronic hepatitis $\mathrm{C}$ infection. Psychol Med. 2002;32(1):1-10.

86. Fontana RJ, Hussain KB, Schwartz SM, Moyer CA, Su GL, Lok AS. Emotional distress in chronic hepatitis $C$ patients not receiving antiviral therapy. J Hepatol. 2002;36(3):401-407.

87. Goh J, Coughlan B, Quinn J, O'Keane JC, Crowe J. Fatigue does not correlate with the degree of hepatitis or the presence of autoimmune disorders in chronic hepatitis C infection. Eur J Gastroenterol Hepatol. 1999;11(8):833-838.

88. Foster GR, Goldin RD, Thomas HC. Chronic hepatitis C virus infection causes a significant reduction in quality of life in the absence of cirrhosis. Hepatology. 1998;27(1):209-212.

89. Bonkovsky HL, Woolley JM. Reduction of health-related quality of life in chronic hepatitis $\mathrm{C}$ and improvement with interferon therapy. The Consensus Interferon Study Group. Hepatology. 1999;29(1): 264-270.

90. Carta MG, Hardoy MC, Garofalo A, et al. Association of chronic hepatitis $\mathrm{C}$ with major depressive disorders: irrespective of interferon-alpha therapy. Clin Pract Epidemiol Ment Health. 2007;3:22.

91. Rikkers L, Jenko P, Rudman D, Freides D. Subclinical hepatic encephalopathy: detection, prevalence, and relationship to nitrogen metabolism. Gastroenterology. 1978;75(3):462-469.

92. Tarter RE, Hegedus AM, Van Thiel DH, Schade RR, Gavaler JS, Starzl TE. Nonalcoholic cirrhosis associated with neuropsychological dysfunction in the absence of overt evidence of hepatic encephalopathy. Gastroenterology. 1984;86(6):1421-1427.

93. Weissenborn K, Heidenreich S, Ennen J, Ruckert N, Hecker H. Attention deficits in minimal hepatic encephalopathy. Metab Brain Dis. 2001;16(1-2):13-19.

94. Ferenci P, LockwoodA, Mullen K, Tarter R, Weissenborn K, Blei AT. Hepatic encephalopathy - definition, nomenclature, diagnosis, and quantification: final report of the working party at the 11th World Congresses of Gastroenterology, Vienna, 1998. Hepatology. 2002;35(3):716-721. 
95. Forton DM, Taylor-Robinson SD, Thomas HC. Central nervous system changes in hepatitis C virus infection. Eur J Gastroenterol Hepatol. 2006;18(4):333-338.

96. Weissenborn K, Krause J, Bokemeyer M, et al. Hepatitis C virus infection affects the brain-evidence from psychometric studies and magnetic resonance spectroscopy. J Hepatol. 2004;41(5):845-851.

97. Forton DM, Thomas HC, Taylor-Robinson SD. Quality of life and cognitive function in chronic hepatitis $\mathrm{C}$ - what to measure? J Hepatol. 2003;39(2):272-274.

98. Ortiz M, Jacas C, Cordoba J. Minimal hepatic encephalopathy: diagnosis, clinical significance and recommendations. J Hepatol. 2005;42 Suppl 1:S45-S53.

99. Perry W, Hilsabeck RC, Hassanein TI. Cognitive dysfunction in chronic hepatitis C: a review. Dig Dis Sci. 2008;53(2):307-321.

100. Heeren M, Weissenborn K, Arvanitis D, et al. Cerebral glucose utilisation in hepatitis $\mathrm{C}$ virus infection-associated encephalopathy. J Cereb Blood Flow Metab. 2011;31(11):2199-2208.

101. Grover VP, Pavese N, Koh SB, et al. Cerebral microglial activation in patients with hepatitis $\mathrm{C}$ : in vivo evidence of neuroinflammation. $J$ Viral Hepat. 2012;19(2):e89-e96.

102. Weissenborn K, Ennen JC, Bokemeyer M, et al. Monoaminergic neurotransmission is altered in hepatitis $\mathrm{C}$ virus infected patients with chronic fatigue and cognitive impairment. Gut. 2006;55(11):1624-1630.

103. Taylor-Robinson SD, Buckley C, Changani KK, Hodgson HJ, Bell JD. Cerebral proton and phosphorus-31 magnetic resonance spectroscopy in patients with subclinical hepatic encephalopathy. Liver. 1999;19(5):389-398

104. Bokemeyer M, Ding XQ, Goldbecker A, et al. Evidence for neuroinflammation and neuroprotection in HCV infection-associated encephalopathy. Gut. 2011;60(3):370-377.

105. Heeren M, Weissenborn K, Arvanitis D, et al. Cerebral glucose utilisation in hepatitis $\mathrm{C}$ virus infection-associated encephalopathy. $J$ Cereb Blood Flow Metab. 2011;31(11):2199-2208.

106. Byrnes V, Miller A, Lowry D, et al. Effects of anti-viral therapy and HCV clearance on cerebral metabolism and cognition. J Hepatol. 2012;56(3):549-556.

107. Pattullo V, McAndrews MP, Damyanovich A, Heathcote EJ. Influence of hepatitis $\mathrm{C}$ virus on neurocognitive function in patients free from other risk factors: validation from therapeutic outcomes. Liver Int. 2011;31(7):1028-1038.

108. Kraus MR, Schafer A, Wissmann S, Reimer P, Scheurlen M. Neurocognitive changes in patients with hepatitis $\mathrm{C}$ receiving interferon alfa-2b and ribavirin. Clin Pharmacol Ther. 2005;77(1):90-100.

109. Reichenberg A, Gorman JM, Dieterich DT. Interferon-induced depression and cognitive impairment in hepatitis $C$ virus patients: a 72 week prospective study. AIDS. 2005;19 Supp1 3:S174-S178.
110. Thein HH, Maruff P, Krahn MD, et al. Improved cognitive function as a consequence of hepatitis $\mathrm{C}$ virus treatment. HIV Med. 2007;8(8):520-528.

111. Clifford DB, Evans SR, Yang Y, Gulick RM. The neuropsychological and neurological impact of hepatitis $\mathrm{C}$ virus co-infection in HIVinfected subjects. AIDS. 2005;19 Supp1 3:S64-S71.

112. Cherner M, Letendre S, Heaton RK, et al. Hepatitis C augments cognitive deficits associated with HIV infection and methamphetamine. Neurology. 2005;64(8):1343-1347.

113. Tohme RA, Holmberg SD. Is sexual contact a major mode of hepatitis C virus transmission? Hepatology. 2010;52(4):1497-1505.

114. Winston A, Garvey L, Scotney E, et al. Does acute hepatitis C infection affect the central nervous system in HIV-1 infected individuals? J Viral Hepat. 2010;17(6):419-426.

115. Laskus T, Radkowski M, Bednarska A, et al. Detection and analysis of hepatitis $\mathrm{C}$ virus sequences in cerebrospinal fluid. $J$ Virol. 2002;76(19):10064-10068.

116. Radkowski M, Wilkinson J, Nowicki M, et al. Search for hepatitis C virus negative-strand RNA sequences and analysis of viral sequences in the central nervous system: evidence of replication. $J$ Virol. 2002;76(2):600-608.

117. Fishman SL, Murray JM, Eng FJ, Walewski JL, Morgello S, Branch AD. Molecular and bioinformatic evidence of hepatitis $\mathrm{C}$ virus evolution in brain. J Infect Dis. 2008;197(4):597-607.

118. Forton DM, Karayiannis P, Mahmud N, Taylor-Robinson SD, Thomas HC. Identification of unique hepatitis $\mathrm{C}$ virus quasispecies in the central nervous system and comparative analysis of internal translational efficiency of brain, liver, and serum variants. $J$ Virol. 2004;78(10):5170-5183.

119. Wilkinson J, Radkowski M, Laskus T. Hepatitis C virus neuroinvasion: Identification of infected cells. J Virol. 2009;83(3):1312-1319.

120. Wilkinson J, Radkowski M, Eschbacher JM, Laskus T. Activation of brain macrophages/microglia cells in hepatitis C infection. Gut. 2010;59(10):1394-1400.

121. Fletcher NF, Yang JP, Farquhar MJ, et al. Hepatitis C virus infection of neuroepithelioma cell lines. Gastroenterology. 2010;139(4):1365-1374.

122. Burgel B, Friesland M, Koch A, et al. Hepatitis C virus enters human peripheral neuroblastoma cells - evidence for extra-hepatic cells sustaining hepatitis C virus penetration. J Viral Hepat. 2011;18(8):562-570.

123. Fletcher NF, Wilson GK, Murray J, et al. Hepatitis C virus infects the endothelial cells of the blood-brain barrier. Gastroenterology. 2012;142(3):634-643. e6.

124. Vivithanaporn P, Maingat F, Lin LT, et al. Hepatitis C virus core protein induces neuroimmune activation and potentiates human immunodeficiency virus-1 neurotoxicity. PLoS One. 2010;5(9):e12856.

125. Forton DM. Hepatitis C treatment - clearing the mind. $J$ Hepatol. 2012;56(3):513-514.
Virus Adaptation and Treatment

\section{Publish your work in this journal}

Virus Adaptation and Treatment is an international, peer-reviewed open access journal focusing on the study of virology, viral adaptation and the development and use of antiviral drugs and vaccines to achieve improved outcomes in infection control and treatment. The journal welcomes original research, basic science, clinical \& epidemiological

\section{Dovepress}

studies, reviews \& evaluations, expert opinion and commentary, case reports and extended reports. The manuscript management system is completely online and includes a very quick and fair peer-review system, which is all easy to use. Visit http://www.dovepress.com/ testimonials.php to read real quotes from published authors. 